\title{
Designing Economics Electives with a Significant Writing Component
}

\author{
Helen Schneider \\ Department of Economics, The University of Texas at Austin, Austin, TX, USA \\ Email: h.schneider@eco.utexas.edu
}

How to cite this paper: Schneider, $\mathrm{H}$. (2017). Designing Economics Electives with a Significant Writing Component. Creative Education, 8, 514-522.

https://doi.org/10.4236/ce.2017.84040

Received: March 22, 2017

Accepted: April 16, 2017

Published: April 21, 2017

Copyright $\odot 2017$ by author and Scientific Research Publishing Inc. This work is licensed under the Creative Commons Attribution International License (CC BY 4.0).

http://creativecommons.org/licenses/by/4.0/

\begin{abstract}
This paper presents a design for the structure and assessment of a research paper assignment in an upper level economics elective with a significant writing component. Writing component design focuses on what graduating economics majors should be able to do with the knowledge they acquire in the major and on their ability to create original analysis and empirical models in courses with and without an econometrics prerequisite. The author provides writing workshop and minimal marking approaches to improving the writing skills of undergraduates. Finally, the paper presents the link between main modules of the course and proficiencies we expect from graduating majors.
\end{abstract}

\section{Keywords}

Economics Elective, Draft, Writing, Undergraduate, Teaching, Research

\section{Introduction}

In a recent survey of over 380,000 college students, the National Survey of Student Engagement (NSSE) found that "writing more in college is positively related to active and collaborative learning, student-faculty interaction, and deep learning. It is also positively related to students' gains in learning and development" (NSSE, 2008: p. 11). The report also suggests that faculty who encourage writing multiple drafts are also likely to emphasize deep approaches to learning (NSSE, 2008: p. 21). Thus, writing intensive economics courses do more than just improve students' writing skills. They help students to improve their critical thinking, understanding of the material, and create original economic models. Finally, they improve students' ability to express their ideas in writing and to write in the style of economics discipline thus preparing them for the writing they will do in graduate school and their future employment. A survey of economics departments by McGoldrick (2008) shows that despite writing courses 
being time consuming, over 70 percent of economics departments in the US reported having a formal writing requirement for economics majors. With greater emphasis on writing in college programs, previous literature addresses efforts to incorporate more writing into economics curriculum (Hansen, 1993; Cohen \& Spencer, 1993; Simpson \& Carrol, 1999; Crowe \& Youga, 1986; Li \& Simonson, 2016). This paper offers strategies for a design of an upper level economics elective with a significant writing component and provides writing units along with assessment rubrics. Strategies for improving writing quality and proficiencies for undergraduate majors are presented at the end.

\section{Courses with a Significant Writing Component}

Main features of writing intensive classes include:

- Students must write regularly and complete substantial writing projects

- Students' writing must make up a substantial part of the course grade

- There is capped enrollment to allow professors to work closely with each student and to provide sufficient feedback on student's written work

Individual schools may include other requirements. For example, at the University of Texas at Austin students enrolled in writing intensive courses must receive feedback from the instructor to help them improve their writing, and be given an opportunity to revise at least one assignment

Each instructor utilizes writing in unique ways to enhance the class for students. In some courses students are required to write a short paper every week, for example, or students may have several writing assignments that build into a single detailed paper. In some classes students may work collaboratively on writing projects. All of these activities are designed to help students master course content and hone their writing skills. In this paper I will concentrate on two designs: a significant research paper with drafts and a series of short papers with no drafts.

\section{Research Paper with Drafts}

This approach is built on the belief that the professor's comments are most effective when a student has an opportunity to revise the paper and incorporate the comments to ensure improvement. In a one semester course a paper with two or three stages allows students to develop their analysis and revise original submissions. Presented structure is as follows:

1) Proposal, $10 \%$ of the grade

2) First Draft, $20 \%$ of the grade

3) Peer Review, $5 \%$ of the grade

4) Final Paper, $15 \%$ of the grade

Writing assignments constitute $50 \%$ of the grade, which is a common requirement for a course with a significant writing component.

\subsection{Proposal Stage}

Although writing a research paper proposal is an optional stage, it gives the stu- 
dents an opportunity to start working on a paper early in the semester and to turn in a proposal early on. The proposal serves as an introduction to the paper upon which students will build later on as more theoretical and empirical models are covered in class.

The proposal should state the question or policy a student wants to address, discuss the importance of the study (i.e. why it is an important public policy issue) and it should include some literature review. Reviewing proposals is also important since the student should not be changing topics and re-writing the paper after the first draft. Ideally, a student should be improving and revising the paper after the next step. Important learning objectives for this stage of the research paper development are: ability to narrow down on a topic, to conduct scholarly literature search and to provide a review of previous literature. Table 1 presents a sample grading rubric and provides description for all of the components of a successful proposal.

Picking an appropriate topic may or may not be a part of the grading rubric. I require students to pick a current actual policy for their analysis. In courses where the instructor provides a topic or topic area, more emphasis should be placed on market failures, justifications for government intervention, and literature review.

Scholarly literature search is an important part of economic research and academic writing in general. Experience shows that undergraduate students are often unable to distinguish scholarly and popular literature. I found that without proper discussion the vast majority of students simply use Google search for literature review and do not present reputable sources. I worked with a University of Texas librarian to design a website with links to the University of Texas Libraries databases, EconLit, JSTOR, Google Scholar, Environment Index, PubMed and other scholarly databases of academic publications. My sample literature search guide for public finance is available here:

http://guides.lib.utexas.edu/c.php?g=557256\&p=3832481

Teaching students to conduct a literature search enhanced the quality of literature review and provided them with research tools for other courses within and outside of economics.

\subsection{First Draft of the Research Paper}

When their paper topic is approved, student moves on to the next stage, first draft. The first draft should be a complete draft, with updated introduction from

Table 1. Suggested proposal grading rubric.

\begin{tabular}{|c|c|c|c|c|c|}
\hline Topic & Importance of the study & Literature review & References $^{1}$ & Writing quality & Due date \\
\hline $\begin{array}{c}\text { Picks a narrow } \\
\text { topic within a field } \\
\text { (e.g. energy } \\
\text { economics) } 40 \%\end{array}$ & $\begin{array}{l}\text { Justifies importance of the } \\
\text { study/reasons for } \\
\text { government intervention } 15 \%\end{array}$ & $\begin{array}{l}\text { Reviews several previous } \\
\text { research papers on } \\
\text { chosen or similar } \\
\text { topic/policy } 20 \%\end{array}$ & $\begin{array}{l}\text { All outside } \\
\text { sources and } \\
\text { numbers are } \\
\text { referenced 5\% }\end{array}$ & $\begin{array}{c}\text { No grammatical } \\
\text { errors with clear and } \\
\text { correct use of English } \\
10 \%\end{array}$ & Met $10 \%$ \\
\hline
\end{tabular}

${ }^{1}$ Failure to reference outside sources, plagiarism and scholastic dishonesty will result in zero grade for the assignment or for the course. 
the proposal stage of the paper, theoretical model, empirical model, conclusions and policy implications. If proposal stage was omitted, some weight should also be placed on topic selection. The most important part of the first draft and the paper overall is student's original analysis of the topic. I always emphasize that literature review is just a small part of the introduction. Theoretical and empirical models from other studies are not a substitute for developing original analysis. At this stage students have to apply one theoretical model presented in class to the topic of their choice. For example, if a student chose to analyze the effect of the Affordable Care Act on health care premiums, he/she can apply Akerlof (1970) market for lemons model to make theoretical predictions about the effect of Obamacare on health insurance premiums. If student chose the carbon tax proposal in Washington as a topic of interest, he/she can use the negative externalities model or emissions fees model to illustrate the effect of the policy on efficiency in that market. I encourage students to illustrate their theoretical analysis with a graphical presentation if appropriate. The writer must clearly show the effect of the policy on the current state of the market. If student's graphs are not incorporated into the text of the paper, they have to provide a clear connection between graphs and text. The goal is to illustrate proficiency in conducting original analysis and original writing, thus I only allow minimal literature review (if any) in this part.

I also require that students propose an empirical model to analyze predictions of their theoretical model. I do not require any data collection since I do not want students to be constrained by what data they could find. Students have to specify what data they would need and which model they can use to estimate the effect of the policy change or the effect of the market change. For example, students analyzing the effect of the Affordable Care Act on health insurance premiums can test predictions of their adverse selection model by building a difference-in-difference model around Massachusetts health insurance experiment. Ideal data for this model is health insurance premiums data from Massachusetts before and after 2006 when the health insurance mandate was passed. Control group includes health insurance premiums in a similar state (e.g. Connecticut) or the rest of the United States over the same time period. An excellent empirical model should justify a control group and point out potential drawbacks of the model that they propose (e.g. compliance with the mandate was higher in Massachusetts and results may not be generalizable to the US in general). Most importantly, the empirical model should test what the theoretical model predicts.

In econometrics courses or courses with econometrics as a pre-requisite students may be asked to actually collect the data and estimate the model. While I do not require actual data collection in my upper level electives, in two-semester honor thesis courses I use the same design plus students have an opportunity to find the available data that comes closest to their ideal model and actually run their empirical model.

Although most students do not present original empirical results, I believe summarizing the presented literature and theoretical model is an important part 
of research paper writing. Paper conclusions succinctly reconcile predictions of the theoretical model with existing empirical literature or with empirical results presented if data was actually collected and the model estimated.

The grading rubric in Table 2 summarizes all parts of the first draft and shows higher emphasis being placed on original theoretical and empirical models.

Each student submits two copies of the first draft: one is for another class member to read and make suggestions, and the other is for me to read, grade and make suggestions. Asking a student to peer review a paper on a different topic is aimed at enhancing deeper learning of another subject as well as improving the student's writing skills. Each student uses two sets of suggestions to revise their final paper.

\subsection{Peer Review}

A successful peer review process should benefit both the reviewer and the writer and lead to genuine substantial revision. Peer reviews can take many forms from in-class peer review workshops to out-of-class formally written peer reviews to electronic peer reviews on course discussion boards. I think that all peer reviews work best when students have internalized criteria for a research paper through teacher provided rubrics (as in Table 3 ) or teacher prepared peer review sheets. Table 3 presents a grading rubric that combines the rubric with peer review questions. I do not allocate set percentages for the peer review rubric since some students still may not have a topic within the field of study even though it

Table 2.Suggested first draft grading rubric.

\begin{tabular}{|c|c|c|c|c|c|c|c|c|}
\hline Topic & $\begin{array}{l}\text { Importance of } \\
\text { the study }\end{array}$ & $\begin{array}{l}\text { Literature } \\
\text { review }\end{array}$ & Theoretical model & Empirical model & Conclusion & References $^{2}$ & Writing quality & Due date \\
\hline $\begin{array}{l}\text { Should address } \\
\text { topic concerns } \\
\text { if any from } \\
\text { proposal stage }\end{array}$ & $\begin{array}{l}\text { Should address } \\
\text { any comments } \\
\text { from proposal } \\
\text { stage } 5 \%\end{array}$ & $\begin{array}{l}\text { Should contain } \\
\text { literature } \\
\text { review if none } \\
\text { was present in } \\
\text { the proposal } \\
20 \%\end{array}$ & $\begin{array}{l}\text { Applies one } \\
\text { theoretical model } \\
\text { presented in class } \\
\text { to chosen topic } \\
20 \%\end{array}$ & $\begin{array}{c}\text { Applies one } \\
\text { empirical model } \\
\text { (e.g. regression, } \\
\text { difference-in- } \\
\text { difference) to } \\
\text { chosen topic. } 20 \%\end{array}$ & $\begin{array}{c}\text { Reconciles } \\
\text { theoretical } \\
\text { predictions } \\
\text { with previous } \\
\text { literature10\% }\end{array}$ & $\begin{array}{l}\text { All sources } \\
\text { and } \\
\text { numbers } \\
\text { are } \\
\text { referenced } \\
5 \%\end{array}$ & $\begin{array}{l}\text { No grammatical } \\
\text { errors with clear } \\
\text { and correct use } \\
\text { of English } 10 \%\end{array}$ & $\begin{array}{l}\text { Met } \\
10 \%\end{array}$ \\
\hline
\end{tabular}

Table 3. Sample peer review rubric.

\begin{tabular}{|c|c|c|c|c|c|c|c|c|}
\hline Topic & $\begin{array}{c}\text { Importance of the } \\
\text { study }\end{array}$ & $\begin{array}{l}\text { Literature } \\
\text { review }\end{array}$ & Theoretical model & Empirical model & Conclusion & References $^{3}$ & $\begin{array}{l}\text { Writing } \\
\text { quality }\end{array}$ & Due Date \\
\hline $\begin{array}{l}\text { Is topic } \\
\text { interesting } \\
\text { and timely? }\end{array}$ & $\begin{array}{c}\text { Is relevance } \\
\text { well-explained? } \\
\text { Are market fail- } \\
\text { ures listed and } \\
\text { explained? }\end{array}$ & $\begin{array}{l}\text { Is relevant } \\
\text { literature } \\
\text { presented? }\end{array}$ & $\begin{array}{l}\text { If theoretical } \\
\text { model is missing, } \\
\text { propose one. } \\
\text { Economics } \\
\text { mistakes should } \\
\text { be pointed out. }\end{array}$ & $\begin{array}{l}\text { If empirical model is } \\
\text { missing, propose one. } \\
\text { Is empirical model } \\
\text { testing what } \\
\text { theoretical model } \\
\text { predicts? }\end{array}$ & $\begin{array}{l}\text { Is there a } \\
\text { logical } \\
\text { conclusion to } \\
\text { the paper? }\end{array}$ & $\begin{array}{l}\text { Does author } \\
\text { provide full } \\
\text { citations and } \\
\text { clear references } \\
\text { in the text? }\end{array}$ & $\begin{array}{l}\text { Is paper } \\
\quad \text { well } \\
\text { written? }\end{array}$ & $\begin{array}{l}\text { Missing due } \\
\text { date on peer } \\
\text { review may } \\
\text { result in } 10 \text { - } \\
100 \text { point } \\
\text { deduction }\end{array}$ \\
\hline
\end{tabular}

${ }^{2}$ Failure to reference outside sources, plagiarism and scholastic dishonesty will result in zero grade for the assignment or for the course.

${ }^{3}$ Failure to reference outside sources, plagiarism and scholastic dishonesty will result in zero grade for the assignment or for the course. 
already have been revised at the proposal stage. For example, it is not unusual for a student to submit a topic in a public finance class on a macroeconomics topic that has nothing to do with public finance. In this case I expect a peer to point it out and the peer review is very short.

Peer reviews are graded based on revision oriented comments rather than simple editing. If original paper does not contain a theoretical or empirical model, I expect a peer to propose one. If empirical model has little to do with theoretical prediction, I expect a peer to provide a better outcome variable or a better model. Economics mistakes should be pointed out. While peers may find simple edits for typos and grammar helpful, I do not allocate much weight to such edits. If a paper is poorly written, a peer can refer the writer to the writing center (more on writing centers below) for help or just point out poor quality writing. In classes with peer review assignments, students submit their final papers together with the comments that they received from their peer. The two assignments are graded together.

\subsection{Final Paper}

The final (revised) paper should address content critiques and improve writing quality. While some students need to address very minor comments, for others it can be a significant re-write. Grades on the final paper are assigned based on how much progress a student made since the first draft and how well a student addressed instructor comments as well as comments of their peer. Two grading approaches possible for final papers with previous drafts:

1) Points are added to the first draft grade based on improvement. In this case students may be given an option not to resubmit a revision if they are satisfied with the grade on their first draft. In this case only their peer review is graded (if peer review is required).

2) Revision is mandatory for credit and the grade since previous draft can decrease if instructor or peer comments are not addressed.

I have used both approaches in the past and they both have their advantages. The first approach incentivizes students to put in more effort into the first draft. The second approach ensures that all students revise their paper and incorporate peer and instructor comments into the final version.

\section{Short Papers with No Drafts}

A survey by Simpson \& Carroll (1999) identified several common types of short papers in writing intensive economics courses. Assignments included op-ed columns, literature review papers, case-study papers, and essay homework. Multiple short paper course design allows students to incorporate feedback on prior assignments into subsequent assignments. Evaluation of papers can take several forms. For example, the first assignment may not be graded and just used by students as a learning exercise to improve writing on subsequent papers. Thus, even when using papers with no drafts it is possible to work sequentially on improving economic content and effectiveness of writing presentation. The grading 
rubric for my short papers is similar to that in Table 2 but without an empirical model. I place greater emphasis on succinct theoretical analysis of the proposed question. In econometrics courses, the theoretical model can be omitted and empirical part of the paper receives a more prominent role. Literature review papers are similar to proposal writing with structure presented in Table 1. Short papers can also be combined with a more substantial research paper.

\section{Content vs. Quality of Writing}

In economics classes most of the emphasis is placed on teaching economic theory and developing the student's ability to apply the same abstract model to different real-life policies. Therefore, instructor grading and peer review grades are based on economic content. At the same time, courses with a significant writing component should help students to grow as writers. In the worst case scenario, poor quality writing can actually impede understanding of the economic content. Writing centers are rich resources for students at any stage of their writing. (If your school does not have one, lobby for one). I find them especially useful when students are referred to them early in the writing process, rather than using them as last minute fixes for weak writers. While writing centers do not provide help with economic content, they can help students to brainstorm for ideas, overcome writer's block, clarify ideas and improve organization and writing style. They also provide an invaluable view on a paper from non-economist perspective.

For poorly written papers instructors can directly refer students to writing center for help. While editing the entire paper for grammar can be prohibitively expensive in terms of time, I find that minimal marking reduces the amount of time spent correcting errors and helps me address issues of grammar and correctness. Minimal marking is based on Haswell (1983) and allows professor identifying all grammar, punctuation and spelling errors for just one representative paragraph of the paper. I bracket the paragraph and circle all mistakes that I consider to be unacceptable. I expect students to correct all mistakes in the bracketed paragraph as well as similar mistakes in the rest of their paper. Figure 1 shows an example of minimal marking from my health economics class.

Although the piece of writing displayed in Figure 1 is not representative of students at the University of Texas at Austin it does show that poor writing style can impede understanding of economic content. Haswell (1983) found that students can correct up to $76.3 \%$ of their own errors on their own, depending on the type of error. While Haswell did not use drafts, he did not record a grade for any student until all noted corrections were made. The use of minimal marking shortens the act of editing papers and engages students in editing and correcting errors on their own. Writing centers can also provide help with editing entire papers for mistakes indicated in the selected paragraph.

\section{Conclusion: Integrating Writing and Content Goals}

Proficiencies for undergraduate majors focus on what students should be able to 
do with the economics skills they acquire and their ability to apply their knowledge to real life events (Hansen, 2001). Writing in upper level electives presents an important way of pushing students to go beyond the customary passive learning environment that dominates introductory course work. Table 4 summarizes writing assignments and Hansen (2001) proficiencies.

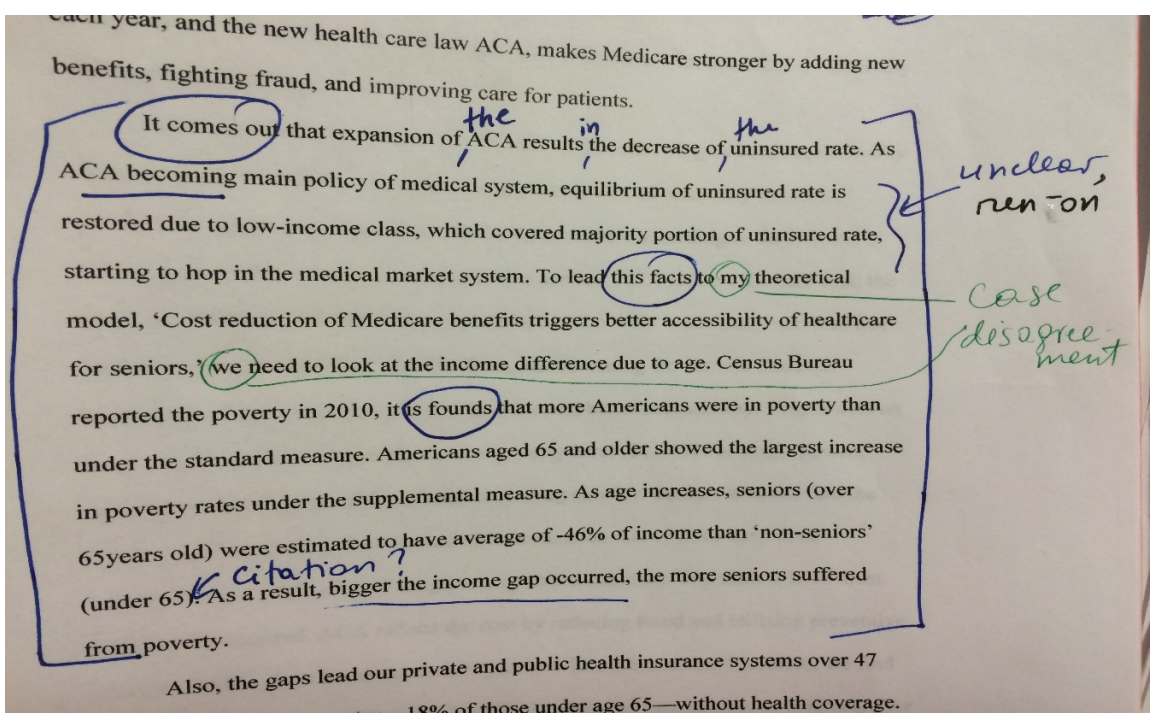

Figure 1. Sample minimal marking from health economics research paper.

Table 4. Integrating writing and proficiency goals.

\begin{tabular}{|c|c|c|}
\hline $\begin{array}{c}\text { Writing } \\
\text { assignment }\end{array}$ & Main learning objectives & Hansen (2001) proficiency goals \\
\hline Proposal & $\begin{array}{l}\text { Students formulate economic research } \\
\text { question, select a narrow topic of their } \\
\text { choice. Students conduct scholarly } \\
\text { literature search and literature review. }\end{array}$ & $\begin{array}{l}\text { Accessing existing knowledge } \\
\text { Displaying existing knowledge } \\
\text { Interpreting existing knowledge }\end{array}$ \\
\hline First draft & $\begin{array}{l}\text { Students apply economic models to } \\
\text { current policies/policy proposals. } \\
\text { Students build original empirical } \\
\text { models. When students collect data } \\
\text { and estimate proposed empirical } \\
\text { model, knew findings are created. }\end{array}$ & $\begin{array}{l}\text { Accessing existing knowledge } \\
\text { Displaying existing knowledge } \\
\text { Interpreting existing knowledge } \\
\text { Applying existing knowledge } \\
\text { Applying quantitative knowledge } \\
\text { Creating new knowledge }\end{array}$ \\
\hline Peer review & $\begin{array}{l}\text { Students provide content feedback to } \\
\text { their peer, ideally on a topic that is } \\
\text { different from the one they chose. } \\
\text { Content help is emphasized. }\end{array}$ & $\begin{array}{l}\text { Accessing existing knowledge } \\
\text { Interpreting existing knowledge }\end{array}$ \\
\hline Final Paper & $\begin{array}{l}\text { Students revise their original papers } \\
\text { based on instructor and peer feedback. }\end{array}$ & $\begin{array}{l}\text { Accessing existing knowledge } \\
\text { Displaying existing knowledge } \\
\text { Interpreting existing knowledge } \\
\text { Applying existing knowledge } \\
\text { Applying quantitative knowledge } \\
\text { Creating new knowledge }\end{array}$ \\
\hline Short paper & $\begin{array}{l}\text { Applying economic models to chosen } \\
\text { or given policy question. }\end{array}$ & $\begin{array}{l}\text { Accessing existing knowledge } \\
\text { Displaying existing knowledge } \\
\text { Interpreting existing knowledge } \\
\text { Applying existing knowledge }\end{array}$ \\
\hline
\end{tabular}


Research paper design alone or combined with peer review presented in this paper can be used in any economics course. Writing assignments require students to read outside of class, help students develop the ability to evaluate and critique the written work of others, and push them to apply original thinking. As they acquire these proficiencies, students learn to think independently as economists and discover what makes good research and writing.

\section{Acknowledgements}

The author is grateful to the anonymous referees and to all of the participants of the writing retreat at the University of Texas at Austin Writing Center for their suggestions and comments.

\section{References}

Akerlof, G. A. (1970). The Market for "Lemons": Qualitative Uncertainty and the Market Mechanism. The Quarterly Journal of Economics, 84, 488-500. https://doi.org/10.2307/1879431

Cohen, A. J., \& Spencer, J. (1993). Using Writing across the Curriculum in Economics: Is Taking the Plunge Worth It? The Journal of Economic Education, 24, 219-230. https://doi.org/10.1080/00220485.1993.10844794

Crowe, D., \& Youga, J. (1986). Using Writing as a Tool for Learning Economics. The Journal of Economic Education, 17, 218-222. https://doi.org/10.1080/00220485.1986.10845169

Hansen, W. L. (1993). Teaching a Writing Intensive Course in Economics. The Journal of Economic Education, 24, 213-218. https://doi.org/10.1080/00220485.1993.10844793

Hansen, W. L. (2001). Expected Proficiencies for Undergraduate Economics Majors. The Journal of Economic Education, 32, 231-242. https://doi.org/10.1080/00220480109596105

Haswell, R. H. (1983). Minimal Marking. College English, 45, 600-604. https://doi.org/10.2307/377147

Li, I., \& Simonson, R. (2016). Capstone Senior Research Course in Economics. The Journal of Economic Education, 47, 161-167. https://doi.org/10.1080/00220485.2016.1146103

McGoldrick, K. M. (2008). Writing Requirements and Economic Research Opportunities in the Undergraduate Curriculum: Results from a Survey of Departmental Practices. The Journal of Economic Education, 39, 287-296.

https://doi.org/10.3200/JECE.39.3.287-296

National Survey of Student Engagement (NSSE) (2008). Promoting Engagement for All Students: The Imperative to Look within 2008 Results. http://nsse.indiana.edu/NSSE_2008_Results/docs/withhold/NSSE2008_Results_revised 11-14-2008.pdf

Simpson, M. S., \& Carroll, S. E. (1999). Assignments for a Writing-Intensive Economics Course. The Journal of Economic Education, 30, 402-410.

https://doi.org/10.1080/00220489909596097 
Submit or recommend next manuscript to SCIRP and we will provide best service for you:

Accepting pre-submission inquiries through Email, Facebook, LinkedIn, Twitter, etc. A wide selection of journals (inclusive of 9 subjects, more than 200 journals)

Providing 24-hour high-quality service

User-friendly online submission system

Fair and swift peer-review system

Efficient typesetting and proofreading procedure

Display of the result of downloads and visits, as well as the number of cited articles Maximum dissemination of your research work

Submit your manuscript at: http://papersubmission.scirp.org/

Or contact ce@scirp.org 